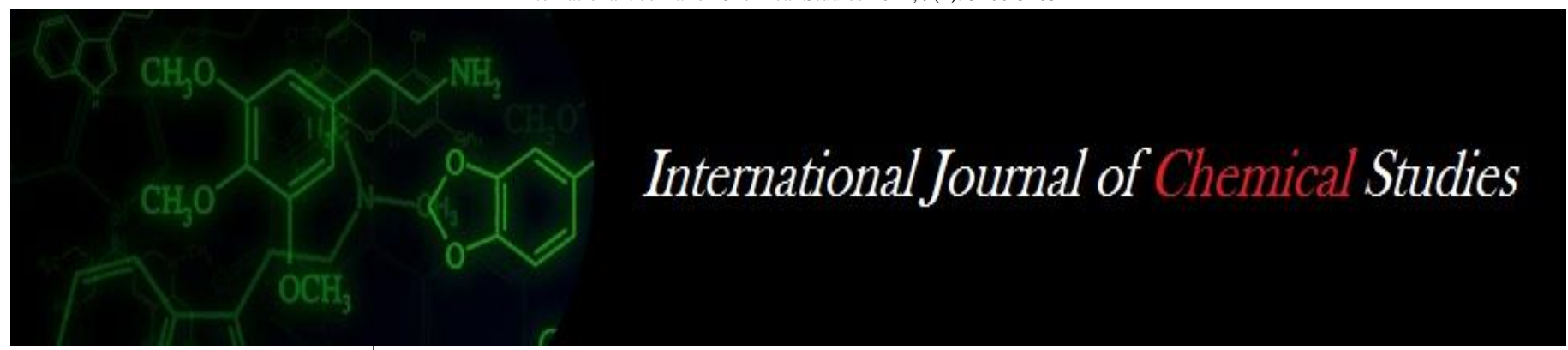

P-ISSN: 2349-8528

E-ISSN: 2321-4902

www.chemijournal.com

IJCS 2021; 9(1): 3100-3103

(C) 2021 IJCS

Received: 19-10-2020

Accepted: 30-12-2020

Pinki Meena

SKN College of Agriculture,

SKN Agriculture University,

Jobner, Jaipur, Rajasthan, India

BS Chandrawat

SKN College of Agriculture,

SKN Agriculture University,

Jobner, Jaipur, Rajasthan, India

RR Ahir

SKN College of Agriculture,

SKN Agriculture University,

Jobner, Jaipur, Rajasthan, India

AK Meena

SKN College of Agriculture,

SKN Agriculture University,

Jobner, Jaipur, Rajasthan, India

Mahabeer Singh

SKN College of Agriculture,

SKN Agriculture University,

Jobner, Jaipur, Rajasthan, India

Corresponding Author:

Pinki Meena

SKN College of Agriculture,

SKN Agriculture University,

Jobner, Jaipur, Rajasthan, India

\section{Management of tomato root-knot wilt complex caused by Meloidogyne incognita and Fusarium oxysporum f. sp. lycopersici through plant extracts}

\author{
Pinki Meena, BS Chandrawat, RR Ahir, AK Meena and Mahabeer Singh
}

DOI: https://doi.org/10.22271/chemi.2021.v9.i1aq.11705

\begin{abstract}
Efficacy of different plant extracts were evaluated against root-knot wilt disease complex of tomato caused by Meloidogyne incognita and Fusarium oxysporum f. sp. lycopersici. Plant extracts were used both as seed treatment and seedling treatment with $2 \%$ concentration. Among tested plant extracts, NSKE was found most effective that reduces nematode population (No of Galls/ plant 20.68 \& No of Egg masses/ plant 15.67) and wilt disease incidence 21.64 followed by garlic clove, it also significantly increase plant growth parameters (shoot length $53.07 \mathrm{~cm}$, root length $19.37 \mathrm{~cm}$, shoot weight $29.63 \mathrm{~g}$ fresh $\& 7.30 \mathrm{~g}$ dry and root weight $7.61 \mathrm{~g}$ fresh $\& 2.25 \mathrm{~g}$ dry).
\end{abstract}

Keywords: Plant extracts, tomato, wilt, Meloidogyne incognita, Fusarium oxysporum

\section{Introduction}

Tomato (Solanum lycopersicum Mill.) is the second most important vegetable belongs to the family Solanaceae. Tomato crop suffers from various phytopathogenic diseases. Among the fungal diseases, Wilt disease caused by Fusarium oxysporum f. sp. lycopersici ${ }^{[1]}$ is most important disease and is limiting factor in tomato production. The fungus also develops synergistic relationship with Meloidogyne spp. leading to root-knot wilt disease complex ${ }^{[2]}$. The first recorded case of a nematode-fungus interaction was made by Atkinson, $1892^{[3]}$, who observed that fusarium wilt of cotton (caused by Fusarium oxysporum f. sp. vasinfectum) was more severe in the presence of root- knot nematodes (Meloidogyne spp.). This complex is highly destructive to tomato plants and is characterized by enhanced wilt symptoms ${ }^{[4]}$. Root knot infection causes $24-26 \%$ loss in tomato ${ }^{[5]}$. A yield loss of $35-39.7 \%$ has been reported due to root-knot nematode infestation on tomato and estimated percentage of loss of 39.77 at 20 larvae /g soil in tomato field in Karnataka ${ }^{[6]}$. Various management strategies have been used extensively over the years to manage the diseases but the use of plant extracts as biopesticides for nematode and fungus disease complex is most economic and environment friendly method. So, the use of plant extracts in Integrated Pest Management (IPM) is now accepted as an ecologically sound alternative to chemical pest control. Thus, the present experiment was conducted to management of the wilt disease complex caused by Meloidogyne incognita and Fusarium oxysporum f. sp. lycopersici in tomato using plant extracts as nonchemical approaches.

\section{Materials and Methods}

Preparation and maintenance of pure culture of Fusarium oxysporum

Diseased samples were collected from farmer's field of the tomato growing areas of Jaipur district and brought to the laboratory of Department of Plant Pathology, S.K.N. College of Agriculture, Jobner for isolation and further examination.

Tomato roots were washed and then cut into small pieces. These pieces were surface sterilized in 1 per cent sodium hypochlorite solution for $1-1 \frac{1}{2}$ minute followed by three consecutive washing with sterilized distilled water, the pieces were transfer to potato dextrose agar medium in petri plates and incubated at $25+1{ }^{\circ} \mathrm{C}$ in BOD incubator for 7 days. The fungal colonies emanating from bits were examined on 7 days of incubation. Pure culture of the fungus was obtained by Single Spore Technique. 
The fungus was multiplied on pre-soaked sterilized sorghum grain in flask by inoculating with 7 days old culture of Fusarium oxysporum f. sp. lycopersici and incubated at $25 \pm 1$ ${ }^{\circ} \mathrm{C}$ temperature for 7 days.

\section{Preparation and maintenance of pure culture of} Meloidogyne incognita

Root knot nematode infested tomato plants were collected from the fields of Jaipur district and nearby vegetable growing villages and brought to the laboratory. Egg masses were carefully detached from roots, under a stereoscopic binocular microscope. Egg masses, collected from the infected roots were kept in distilled water in watch glasses at room temperature for hatching. Freshly hatched $2^{\text {nd }}$ stage juveniles were then inoculated on one month old tomato seedlings which were grown and maintained in $20 \mathrm{~cm}$ radius clay pots filled with steam sterilized soil to obtained adequate pure population of $M$. incognita on the plants and in soil to carry out further experiments.

\section{Preparation of plant extract}

Neem seed kernel extract, giloy stem, garlic clove, lantana leaves, aak leaves and tulsi leaves were collected and washed with distilled water. Hundred gram of clean fresh plant parts were ground with $100 \mathrm{ml}$ absolute alcohol. The mixture was allowed to stand for 48 hours at room temperature and subsequently filtered through filter paper. The solvent was completely evaporated from the extract at $70^{\circ} \mathrm{C}$ till it become a semi-solid material. This semi-solid material becomes stock solution by adding distilled water and makes different respective concentration by different plant extracts stock solution.

In-vivo effect of plant extracts on the Fusarium oxysporum f. sp. lycopersici and Meloidogyne incognita infecting tomato

Two per cent concentration was prepared with $2 \mathrm{ml}$ of stock solution and $98 \mathrm{ml}$ of distilled water. Seven tomato seedlings were dipped in six different plant extracts and sown in pots. Distilled water alone serves as control \{Nematode at the time of sowing and fungus one week after $(\mathrm{N} 1+\mathrm{F} 2)\}$. Tomato seedlings of uniform size were dipped in plant extracts. The treated seedlings were transplanted in pot. The experiment was laid out in CRD with five replications. The pots were watered regularly as and when required. Observation on plant growth, reproduction of root-knot nematode and wilt per cent disease incidence on tomato were recorded at 45 days after transplanting. The roots were washed carefully under tap water and stained with 0.1 per cent acid Fuschin lactophenol and after wash kept in clear lacto phenol for $24 \mathrm{hrs}$. Thereafter the roots were examined thoroughly under a stereoscopic binocular microscope for counting number of galls per plant and number of egg masses per plant. The data were subjected to statistical analysis. Total number of treatments was $07\left(\mathrm{~T}_{1^{-}}\right.$ NSKE, $\mathrm{T}_{2}$-Giloy stem, $\mathrm{T}_{3}$-Garlic clove, $\mathrm{T}_{4}$-Lantana leaves, $\mathrm{T}_{5-}$ Aak leaves, $\mathrm{T}_{6}-\mathrm{Tulsi}$ leaves and $\mathrm{T}_{7}-\mathrm{Control}$ ).

\section{Results and Discussion \\ (A) Growth Parameter \\ Shoot Length}

The data indicated that maximum shoot length was recorded with NSKE $(53.07 \mathrm{~cm})$ followed by garlic cloves $(50.10 \mathrm{~cm})$, Aak leaves $(48.23 \mathrm{~cm})$. Rest of the treatment were observed to be inferior to NSKE but significantly superior over control $(21.33 \mathrm{~cm})$.

\section{Root Length}

The data indicated that maximum root length was recorded with NSKE $(19.37 \mathrm{~cm})$ followed by garlic cloves $(18.03 \mathrm{~cm})$ and Aak leaves $(16.87 \mathrm{~cm})$ over control $(8.27 \mathrm{~cm})$.

\section{Shoot Weight}

The maximum shoot weight was recorded with NSKE (29.63 $\mathrm{g}$ fresh and $7.30 \mathrm{~g}$ dry) followed by garlic clove (27.78 $\mathrm{g}$ and $6.68 \mathrm{~g})$ and aak leaves $(26.41 \mathrm{~g}$ and $5.53 \mathrm{~g})$. While, minimum recorded in control $(4.01 \mathrm{~g}$ and $0.54 \mathrm{~g})$.

\section{Root Weight}

The maximum root weight was recorded with NSKE (7.61 g fresh and $2.25 \mathrm{~g}$ dry) followed by garlic clove (7.01 $\mathrm{g}$ and $1.99 \mathrm{~g})$ and aak leaves $(6.59 \mathrm{~g}$ and $1.80 \mathrm{~g})$.

\section{(B) Nematode Reproduction}

\section{No. of Root Galls}

Number of galls were significantly reduced in NSKE (20.68) as compared to control where maximum (41.27) galls were recorded, followed by Garlic clove recorded (22.35) and aak leaves (25.11). Rest of the treatments were inferior over these but superior over control.

\section{No. of Egg Masses}

Number of egg masses were significantly and drastically reduced in NSKE (15.67) as compared to control where maximum (32.67) egg masses were recorded.

\section{(C) Wild Incidence}

\section{Percent disease incidence}

Among all the treatments minimum per cent disease incidence of wilt was recorded with NSKE $(21.64 \%)$ followed by garlic clove $(23.01 \%)$ and Aak leaves $(26.56 \%)$. All the treatments significantly reduce wilt disease incidence of wilt as compared to control (61.37\%).

Table 1: Efficacy of Plant extracts (botanicals) on tomato plant growth parameters

\begin{tabular}{|c|c|c|c|c|c|c|}
\hline \multirow{2}{*}{ Treatments } & \multirow{2}{*}{$\begin{array}{c}\text { Shoot Length } \\
(\mathrm{cm})\end{array}$} & \multirow{2}{*}{$\begin{array}{c}\text { Root Length } \\
(\mathrm{cm})\end{array}$} & \multicolumn{2}{|c|}{ Shoot weight (g) } & \multicolumn{2}{|c|}{ Root weight (g) } \\
\hline & & & Fresh & Dry & Fresh & Dry \\
\hline NSKE & 53.07 & 19.37 & 29.63 & 7.30 & 7.61 & 2.25 \\
\hline Giloy stem & 37.23 & 12.43 & 19.16 & 4.06 & 4.94 & 1.17 \\
\hline Garlic clove & 50.10 & 18.03 & 27.78 & 6.68 & 7.01 & 1.99 \\
\hline Lantana leaves & 46.30 & 15.73 & 23.78 & 4.97 & 5.73 & 1.61 \\
\hline Aak leaves & 48.23 & 16.87 & 26.41 & 5.53 & 6.59 & 1.80 \\
\hline Tulsi leaves & 42.03 & 14.77 & 21.47 & 4.48 & 5.37 & 1.38 \\
\hline Control (N1+F2) & 21.33 & 8.27 & 4.01 & 0.54 & 0.74 & 0.52 \\
\hline S.Em\% & 0.653 & 0.768 & 0.636 & 0.328 & 0.483 & 0.166 \\
\hline $\mathrm{CD}$ at $5 \%$ & 1.957 & 2.303 & 1.905 & 0.985 & 1.447 & 0.498 \\
\hline
\end{tabular}

*Average of five replications

NSKE $=$ Neem Seed Kernel Extract 
Table 2: Efficacy of plant extracts (botanicals) on wilt (Fusarium oxysporum f. sp. lycopersici) incidence and Meloidogyne incognita interaction in tomato

\begin{tabular}{l|c|c|c|}
\hline Treatments & No of Galls/ plant & No of Egg masses/ plant & PDI \\
\hline NSKE & 20.68 & 15.67 & $21.64(27.72)$ \\
\hline Giloy stem & 34.02 & 26.00 & $42.9(40.92)$ \\
\hline Garlic clove & 22.35 & 18.00 & $23.01(28.66)$ \\
\hline Lantana leaves & 28.69 & 21.00 & $32.97(35.04)$ \\
\hline Aak leaves & 25.11 & 19.32 & $26.56(31.02)$ \\
\hline Tulsi leaves & 30.54 & 23.67 & $40.37(39.44)$ \\
\hline Control (N1+F2) & 41.27 & 32.67 & $61.37(51.57)$ \\
\hline SEm\% & 0.198 & 1.037 & 0.893 \\
\hline CD at 5\% & 0.592 & 3.108 & 2.677 \\
*Average of five replications & & \\
Figures given in parenthesis are angular transformed value \\
NSKE = Neem Seed Kernel Extract
\end{tabular}

The present investigation revealed that among different plant extracts (NSKE, Giloy stem, Garlic clove, Lantana leaves, Aak leaves and Tulsi leaves), NSKE found most effective followed by garlic cloves and aak leaves in increase in plant growth parameters (shoot length, root length, shoot weight and root weight) and reduction in number of galls, egg masses and per cent disease incidence. Similar results were reported on tomato ${ }^{[7]}$ and green gram ${ }^{[8]}$. Kumar and Khanna, $2006^{[9]}$ reported significant and improved plant growth by effectively reducing nematode population by applying NSKE followed by Eco neem. Neem products were more toxic (NSKE as compare to NSE) to Meloidogyne incognita than to
Cephalobus persegnis and followed by Heterorhabditis indica [10]. Similarly, garlic cloves extract found effective in reduction of number of galls, egg masses on roots and juveniles of M. incognita in soil. Similar results were reported by Youssef et al., $2016^{[11]}$. Similarly, Aak leaves were effective in reduction of the soil nematode population \{Saravanapriya and Sivakumar, $2005^{[12]}$ and Patel et al., $\left.1993^{[13]}\right\}$. Application of neem cake significantly decrease the root-knot nematode population on tomato ${ }^{[14]}$, neem leaves powder ${ }^{[15,16]}$, Calotropis procera and Aloe vera ${ }^{[17]}$ was found to be the most effective in improving growth of maize and reducing infection of Heterodera zeae.
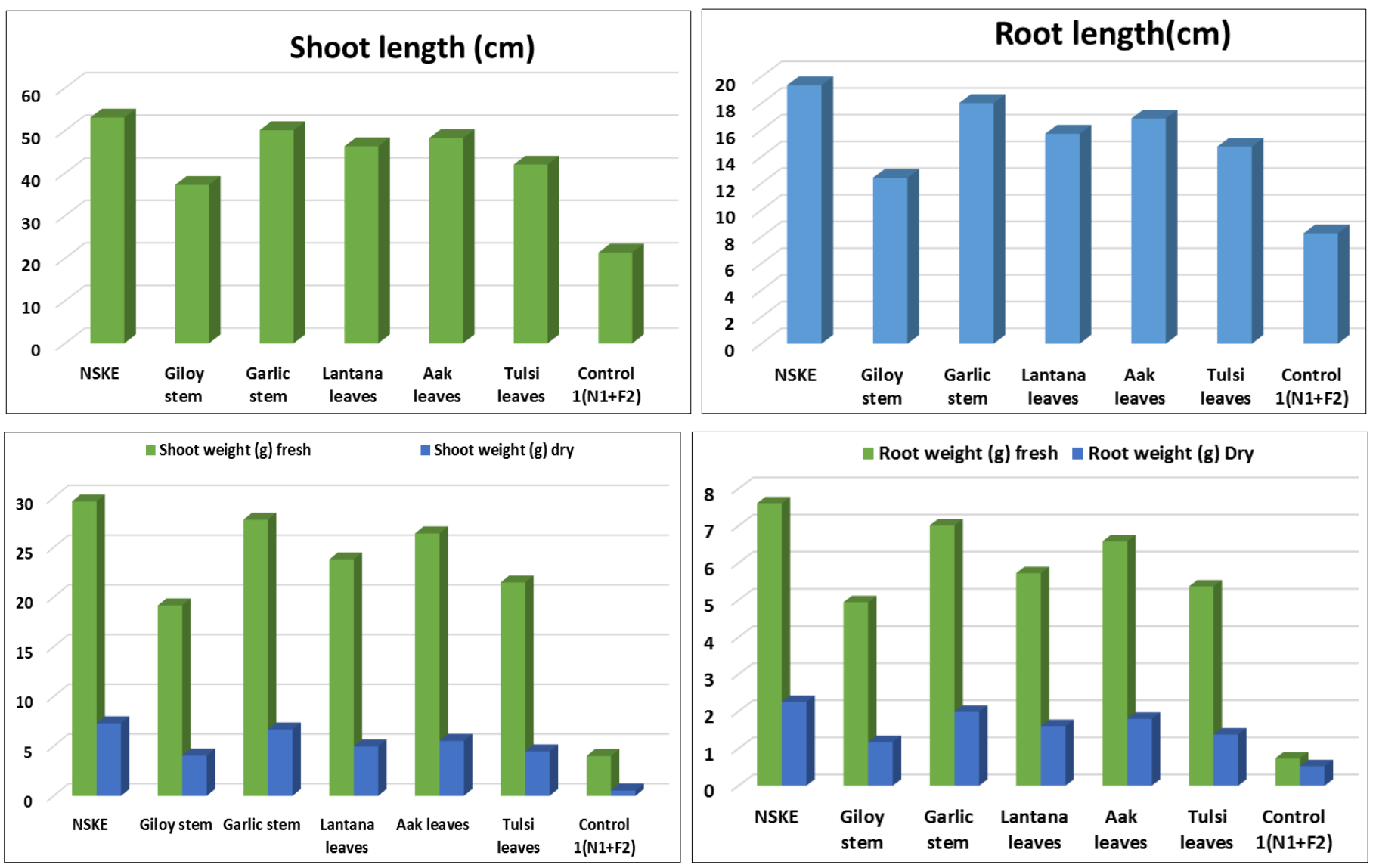


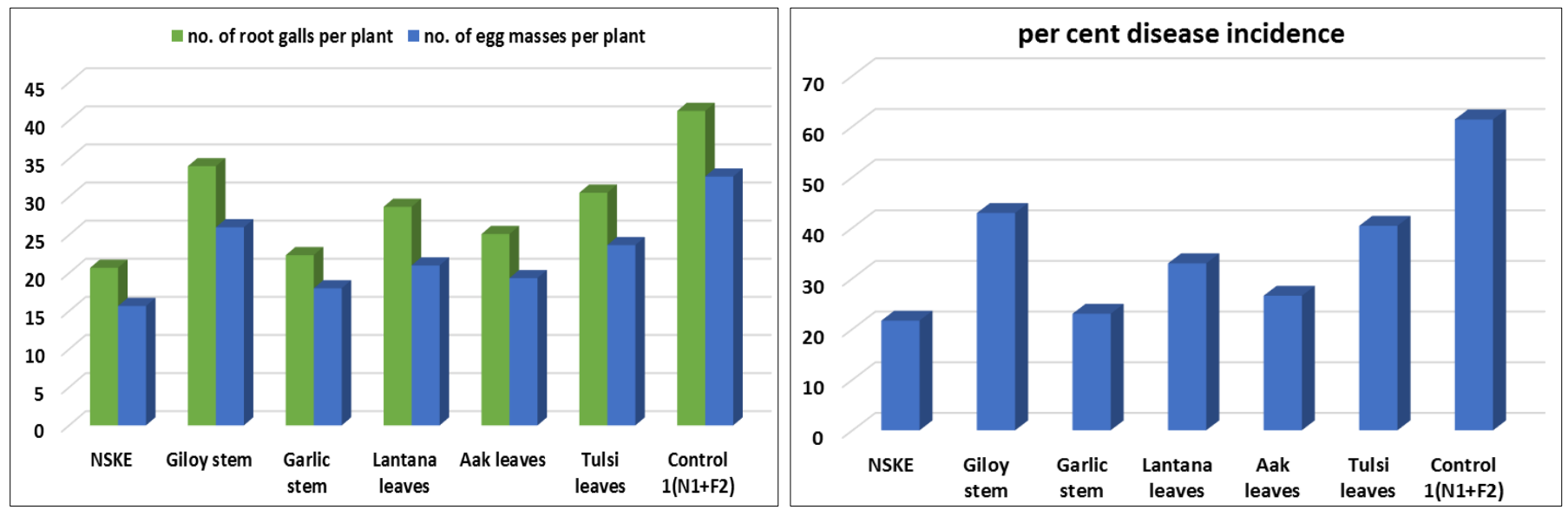

Fig 1: Efficacy of various plant extracts (botanicals) on wilt (Fusarium oxysporum f. sp. lycopersici) incidence and Meloidogyne incognita in tomato under pot condition

\section{References}

1. Singh RS. Plant disease $9^{\text {th }}$ edition oxford \& IBH publishing company Pvt. Ltd. 113-B Shahpur Jat, Asian Games Village New Delhi 110049, India 2009.

2. Patel BA, Patel DJ, Patel RG. Interaction between Meloidogyne incognita and wilt inducing fungus, Fusarium oxysporum f. sp. ciceri on chickpea cv. Dahod yellow. Indian Journal Nematology 2000;30(2):133-135.

3. Atkinson GF. Some diseases of cotton. Alabama Agriculture Experiment Station Bulletien 1892;41:65.

4. Prasad D. Wilt disease of tomato caused by Fusarium oxysporum f. sp. lycopersici in presence or absence of Meloidogyne incognita. Annual Plant Protection Science 1995;3:141-144.

5. Sasser JN. Economic importance of Meloidogyne in tropical countries. In root- knot nematode (Meloidogyne spp.): systematics, biology and control. (Eds. Lamberti, F. and Taylor, C. E.). Academic Press, London, 477, 1979, 359-374.

6. Reddy DDR. Analysis of crop losses in tomato due to Meloidogyne incognita. Indian Journal of Nematology 1985;15:55-59.

7. Hadian S, Rahnama K, Jamali S, Eskandari A. Comparing Neem extract with chemical control on Fusarium oxysporum and Meloidogyne incognita complex of tomato. Advances in Environmental Biology 2011;5(8):2052-2057.

8. Haseeb A, Sharma A, Shukla PK. Studies on the management of root-knot nematode, Meloidogyne incognita-wilt fungus, Fusarium oxysporum disease complex of green gram, Vigna Radiata cv ML-1108. Journal of Zhejiang University Science 2005;68(8):736742.

9. Kumar S, Khanna AS. Effect of neem-based products on the root knot nematode, Meloidogyne incognita and growth of tomato. Nematologia Mediterranea 2006;34:141-146.

10. Ardakani AS, Gaur HS, Kamra A, Mohan S. Impact of Azadirachta indica seed and kernel extracts on Melodogyne incognita, cephalobus persegnis and Heterorhabditis indica. International Journal of Nematology 2009;19(1):87-95.

11. Yossef MMA, Wafaa M, El-Nagdi, Lashein AMS. Comparative study on the effect of garlic clove and acetyl salicylic acid aqueous extracts with emphasis on inducing resistance against root knot nematode, Meloidogyne incognita on Sugar beet. International Journal of Pharm Tech Research 2016;9(10):01-07.

12. Saravanapriya B, Sivakumar M. Management of root knot nematode Meloidogyne incognita on tomato with botanicals. Indian Journal of Natural Products and Resources 2005;4(3):158-161.

13. Patel DJ, Patel HV, Patel BA. Nematicidal properties of some plant materials for the management of root knot nematode in tomato nursery. Indian Journal of Plant Protection 1993;21:242-244.

14. Chandrawat BS, Siddiqui AU, Bhati SS, Saharan Vinod. Response of defence related enzymes in tomato treated with oil-cakes against root-knot nematode, Meloidogyne incognita. International Journal of Current Microbiology and Applied Sciences 2020;9(11):1100-1111.

15. Meena KK, Baheti BL, Rathore BS, Chandrawat BS. Organic amendment-An important tool for the management of maize cyst nematode, Heterodera zeae on maize (Zea mays L.). Current Nematology 2014;26(1,2):23-27.

16. Baheti BL, Meena KK, Chandrawat BS, Khandelwal SK, Singh Dilip. Botanicals: an effective tool to check the initial infection of maize cyst nematode, Heterodera zeae on maize as seed treatment. Advances in life sciences 2016;5(11):4502-4506.

17. Kumhar RN, Baheti BL, Chandrawat BS. Eco-friendly management of maize cyst nematode, Heterodera zeae on maize by use of botanicals. International Journal of Current Microbiology and Applied Sciences 2018;7(6):199-204. 